Anna Kristina M. Hernandez, MD Arsenio Claro A. Cabungcal, MD

Department of Otorhinolaryngology Philippine General Hospital University of the Philippines Manila

\section{Maxillary Sinus Squamous Cell Carcinoma in a Tertiary Hospital in the Philippines}

\author{
ABSTRACT \\ Objective: To establish preliminary demographic and clinicopathologic data on Maxillary Sinus \\ Squamous Cell Carcinoma (SCC) in the Philippine General Hospital
}

\section{Methods:}

\section{Design: \\ Retrospective Case Series \\ Setting: Tertiary National University Hospital}

Participants: Socio-demographic and clinical data from records of 22 patients admitted at the Department of Otorhinolaryngology of the Philippine General Hospital from 2013-2016 and histopathologically confirmed to have Maxillary Sinus SCC were collected and described using means and proportions.

Results: There were 15 males and 7 females with a mean age of 50 years old (range 24 to 77 years old). Maxillary mass/swelling was the most common chief complaint. The mean gap between initial symptoms and consult was 6.77 months. Initial biopsies were obtained from the maxillary sinus in 16 patients, with 1 patient noted to have undergone malignant transformation from a prior intranasal squamous papilloma. Staging was advanced (Stage IVA in 16, IVB in 4, and III in 2) with no patients with Stage I or II disease. Sixteen (16) patients underwent surgery and radiotherapy while 6 patients received radiotherapy (RT) with or without chemotherapy. Regional and distant metastases were uncommon.

Conclusion: In this series, maxillary sinus SCC occurs more in males with a maxillary mass as the most common chief complaint. Delay in treatment is common with a mean gap of 6 months between initial symptoms and consult. Neck node metastasis is uncommon and most patients undergo surgery with radiotherapy as treatment.

\section{Keywords: maxillary sinus cancer; paranasal sinus cancer; squamous cell carcinoma}

Maxillary sinus squamous cell carcinoma (SCC) is a rare cancer, comprising about $0.2-0.8 \%$ of all malignant neoplasms ${ }^{1,2}$ and $3 \%$ of all head and neck malignancies. ${ }^{1}$ It is the most common histopathologic type among maxillary cancers. ${ }^{1,3,4}$ This disease is extremely rare in children with those between the ages of 55 to 65 years old usually affected. ${ }^{1}$ It usually presents in advanced stages in patients who are often treated for benign conditions before malignancy is diagnosed and the overall 5 -year survival is at $42 \%$.

There have been reports of varying clinical behavior among Maxillary SCC in various regions worldwide through the years. Aggressive presentation and rapid onset of maxillary carcinomas are rarely seen in western Europe ${ }^{5}$ while prevalence of cervical metastasis at initial presentation has been observed in India., 3 Survival has improved through the years but conflicting results depending on the modality of treatment have also been reported. ${ }^{3,-9}$ 
ORIGINAL ARTICLES

Local studies tend to focus more on head and neck malignancies in general and a literature search of MEDLINE (PubMed) and HERDIN using the search terms Maxillary Sinus Cancer (MeSH Term) AND Squamous Cell Carcinoma (MeSH Term) AND Philippines (All Fields) did not yield specific studies on maxillary sinus SCC. The rarity of this disease, along with varying findings in the literature necessitates the establishment of baseline data for maxillary sinus SCC. This paper aims to establish preliminary sociodemographic and clinicopathologic data on maxillary sinus SCC in our institution.

\section{METHODS}

With institutional review board approval, this retrospective case series considered for inclusion the records of patients admitted at the Philippine General Hospital Department of Otorhinolaryngology public ward from January 1, 2013 - December 31, 2016 who were diagnosed with histopathologically-confirmed maxillary sinus SCC. Records of patients diagnosed with other cancers of the maxillary sinus, residual or recurrent maxillary sinus SCC, and those with incomplete records were excluded.

We reviewed the patient database of the Department of Otorhinolaryngology to determine eligible patients for this study. Patient records were coded and de-identified socio-demographic data such as age, sex, location, past medical history, family medical history, personal social history, as well as clinical data including chief complaint, time between symptom onset and initial consult, signs/symptoms, staging ( $\mathrm{T}, \mathrm{N}, \mathrm{M})$, biopsy approach, histopathologic diagnosis/grading, intraoperative anatomic involvement, regional metastasis and distant metastasis were extracted from patient records. Data were written in data collection sheets and subsequently encoded in a Microsoft Excel Office 365 database. Data were checked for accuracy of encoding. Data analysis utilized Microsoft Excel version 1903 (Microsoft Corp. Redmond, WA, USA) to generate descriptive analysis. Means and proportions were used to describe the study variables.

\section{RESULTS}

Out of 25 patient records identified, 22 patients (15 males, 7 females) with ages 24 to 77 years old (mean age 50 years old) were included. Excluded were one record for incompleteness and 2 for non-SCC biopsy results. Twenty (20) patients were from Luzon, 2 from Visayas, none from Mindanao. Nineteen (19) of the 22 patients consulted within 6 months of initial symptoms with a chief complaint of mass or swelling in 21 and nasal obstruction in 1. Eleven (11) patients had a history of smoking, 15 had a history of alcohol ingestion and 11 had a history of both. Only three (3) patients had a history of Schedule 1 (high abuse potential) drug use. Nine (9) patients had comorbidities but only one (1) patient had a prior intranasal (not maxillary) mass while two (2) patients had prior intranasal (not maxillary) surgeries. The employment of patients varied, 3 were carpenters/construction workers, 3 were jeepney drivers/dispatchers, 2 each were security guards, fishermen farmers, housewives, or retired, 1 each was a seamstress, animator, cashier, and mechanic, and 2 listed no occupation.

Initial biopsies were mostly taken from the maxillary sinus $(n=16)$ and resulted in a diagnosis of squamous cell carcinoma for all patients with 1 patient noted to have undergone malignant transformation from a prior intranasal squamous papilloma. Staging was advanced in all (Stage IVA in 16, IVB in 4, and III in 2) with no patients staged I or II in this series. Sixteen (16) patients underwent surgery with radiotherapy, the rest were advised radiotherapy with or without chemotherapy. Eleven (11) patients with advanced staging underwent maxillectomy with orbital exenteration.

The most common signs/symptoms are enumerated in Figure 1. Apart from cheek fullness/maxillary swelling, patients also frequently presented with a palatal bulge $(n=20)$. Other pertinent signs/symptoms included are hyposmia $(n=3)$, bleeding mass $(n=3)$, septal deviation $(n=3)$, and skin changes $(n=3)$.

Areas often grossly involved intraoperatively include the oral cavity ( $n=19$; usually the palate and the gingiva), the nasal cavity ( $n=17$; from an intranasal extension of the maxillary mass), and the orbit ( $n=13$; usually through lysis of the orbital floor).

Nine (9) patients presented with clinically palpable neck nodes. Of the nine (9), only five (5) underwent neck dissection and had available post-operative histopathologic results. Three (3) of the five (5) patients



Figure 1. Most Common Signs/Symptoms 
Table 1. Comparison of Maxillary Sinus Cancer Data

\begin{tabular}{|c|c|c|c|c|c|c|}
\hline $\begin{array}{c}\text { Origin } \\
\text { (Authors, } \\
\text { Year } \\
\text { Published) }\end{array}$ & $\begin{array}{c}\text { USA } \\
\text { (St. Pierre \& } \\
\text { Baker, 1983) }\end{array}$ & $\begin{array}{l}\text { Netherlands } \\
\text { (Tiwari, et al. } \\
\text { 1999) }\end{array}$ & $\begin{array}{c}\text { Brazil } \\
\text { (Santos, et al. 2014) }\end{array}$ & $\begin{array}{c}\text { Japan } \\
\text { (Kondo, et al. } \\
\text { 2016) }\end{array}$ & $\begin{array}{c}\text { India } \\
\text { (Qureshi, et al. } \\
\text { 2006) }\end{array}$ & $\begin{array}{l}\text { Philippines } \\
\text { (Hernandez } \\
\text { \& Cabungcal, } \\
\text { 2019)* }\end{array}$ \\
\hline $\begin{array}{l}\text { Number of } \\
\text { Patients }\end{array}$ & $\begin{array}{l}66 \text { patients } \\
(1964-1975)\end{array}$ & $\begin{array}{l}43 \text { squamous cell } \\
\text { carcinoma patients } \\
(1975-1994)\end{array}$ & $\begin{array}{l}58 \text { patients (more } \\
\text { adenocarcinomas } \\
\text { than squamous cell } \\
\text { carcinomas) }\end{array}$ & $\begin{array}{l}26 \text { patients (2002- } \\
2008)\end{array}$ & $\begin{array}{l}73 \text { patients } \\
\text { (1994-1999) }\end{array}$ & $\begin{array}{l}22 \text { patients (2013- } \\
2016)\end{array}$ \\
\hline $\begin{array}{l}\text { Gender } \\
\text { Distribution, } \\
\text { Age }\end{array}$ & $\begin{array}{l}42 \text { Male, } 24 \text { Female } \\
\text { Average age at } 60 \\
\text { years }\end{array}$ & $\begin{array}{l}28 \text { Male, } 15 \text { Female } \\
\text { Age range at 32-90 } \\
\text { years }\end{array}$ & $\begin{array}{l}35 \text { Male, } 23 \text { Female } \\
\text { Median age of } 59 \text { years }\end{array}$ & $\begin{array}{l}18 \text { Male, } 8 \text { Female } \\
\text { Average age at } 64.2 \\
\text { years (50-84 years) }\end{array}$ & \begin{tabular}{|l}
39 Male, 23 \\
Female \\
Median age 55 \\
years
\end{tabular} & $\begin{array}{l}15 \text { Male, } 7 \text { Female } \\
\text { Average age at } \\
50 \text { years ( } 24-77 \\
\text { years) }\end{array}$ \\
\hline $\begin{array}{l}\text { Stage } \\
\text { Distribution }\end{array}$ & $\begin{array}{l}1 \text { Stage I, } 8 \text { Stage } \\
\text { II, } 21 \text { Stage III, } 36 \\
\text { Stage IV }\end{array}$ & $\begin{array}{l}7 \text { Stage II, } 20 \text { Stage } \\
\text { III, } 16 \text { Stage IV }\end{array}$ & $\begin{array}{l}5 \text { Stage I or II, } 53 \text { Stage } \\
\text { III or IV }\end{array}$ & $\begin{array}{l}4 \text { with T2, } 13 \text { with } \\
\text { T3, } 9 \text { with T4a }\end{array}$ & $\begin{array}{l}61 \text { Presented } \\
\text { with T3/T4 } \\
\text { Disease } \\
\end{array}$ & $\begin{array}{l}0 \text { Stage I/II, } 2 \\
\text { Stage III, } 16 \text { Stage } \\
\text { IVA, } 4 \text { Stage IVB }\end{array}$ \\
\hline $\begin{array}{l}\text { Percentage of } \\
\text { Lymph Node } \\
\text { Metastasis } \\
\end{array}$ & $\begin{array}{l}10.6 \% \text { of patients } \\
\text { had lymph node } \\
\text { metastasis }\end{array}$ & & $\begin{array}{l}17.2 \% \text { of patients had } \\
\text { regional metastasis }\end{array}$ & $\begin{array}{l}8 \text { patients had } \\
\text { lymph node } \\
\text { metastasis (30.8\%) }\end{array}$ & $\begin{array}{l}6 \text { presented } \\
\text { with lymph } \\
\text { node metastasis }\end{array}$ & $\begin{array}{l}3 \text { patients had } \\
\text { lymph node } \\
\text { metastasis }\end{array}$ \\
\hline Treatment & Surgery + RT & $\begin{array}{l}\text { Surgery + RT, } \\
\text { Chemotherapy } \\
+\mathrm{RT}\end{array}$ & $\begin{array}{l}\text { Surgery +RT, } \\
\text { Chemotherapy + RT }\end{array}$ & Chemotherapy + RT & $\begin{array}{l}\text { Surgery + RT, } \\
\text { Chemotherapy, } \\
\text { Radiotherapy } \\
\end{array}$ & $\begin{array}{l}\text { Surgery + } \\
\text { RT, RT +/- } \\
\text { Chemotherapy }\end{array}$ \\
\hline Outcomes & $\begin{array}{l}\text { 5-year survival } 75 \% \\
\text { for T2, 28.5\% T3, } \\
19.4 \% \mathrm{~T} 4\end{array}$ & $\begin{array}{l}\text { 5-year disease-free } \\
\text { survival } 64 \% \text { for } \\
\text { Surgery+RT } \\
\text { 2-year survival of } \\
37 \% \text { for Chemo+RT }\end{array}$ & $\begin{array}{l}\text { Overall 5-year survival } \\
\text { rate of } 17.7 \%\end{array}$ & $\begin{array}{l}\text { Overall 5-year } \\
\text { survival rate of } \\
71.3 \%\end{array}$ & $\begin{array}{l}\text { Overall 5-year } \\
\text { survival after } \\
\text { Surgery + RT of } \\
43 \%\end{array}$ & \\
\hline
\end{tabular}

*data from the present series

yielded positive regional metastasis to the cervical lymph nodes.

Diagnostics for distant metastases were normal for most patients including liver ultrasound $(n=18)$, chest $x$-ray $(n=16)$, Aspartate Aminotransferase $(n=16)$, Alanine Aminotransferase $(n=12)$ and Alkaline Phosphatase $(n=14)$. Four (4) patients had remarkable liver ultrasound findings -- 2 had benign findings (hepatic cyst and parenchymal disease), 1 had a hepatic focus measuring $1.8 \mathrm{~cm}$, and another had nonspecific calcifications. Biopsy was not obtained from any of the masses identified. Four (4) patients had significant x-ray findings suggestive of infection (pneumonia in 1 , pulmonary tuberculosis in 3 ).

\section{DISCUSSION}

The general demographic and clinicopathologic profile of patients with maxillary SCC in this series is similar with findings in our literature review from the region. (Table 1) Common symptoms include pain, nasal discharge, epistaxis and obstruction, commonly affecting males more than females at a ratio of 1.5:1. ${ }^{1}$ Other symptoms include: (1) nasal fullness, stuffiness or obstruction, (2) pain, (3) cheek paresthesia, (4) cheek fullness or swelling, (5) palatal bulge, (6) persistent, nonhealing nasal/oral sore or ulcer, (7) nasal mass, (8) proptosis, diplopia or lacrimation.' Similar to existing literature, our study revealed male predominance in this disease - with a male: female ratio of 2.1:1. The presence of a maxillary mass was the most common chief complaint identified.

The development of maxillary sinus cancer appears to be influenced by several factors such as: exposure to (1) nickel, (2) chlorophenols, (3) textile dust, (4) Thorotrast instillation, (5) smoking, (6) formaldehyde, (7) wood, (8) concurrence of sinonasal (Schneiderian) papilloma, and (9) Human Papilloma Virus. ${ }^{1,7}$ However, due to methodological limitations of this study, we were unable to identify these factors in our sample. Smoking and alcohol ingestion were observed in at least half of the patients and were more frequently noted than Schedule 1 drug use. Employment as a construction worker or jeepney driver was more common among the patients in our series. Risk for exposure may be inferred, at best, from the patients' residence or employment.

The dilemma with diagnosing Maxillary Sinus SCC is that tumor growth is usually indolent. Delay in consultation may range from a month to even years, with some patients in this series first consulting ophthalmologists for eye symptoms or dentists for dental symptoms, only to discover that the problem was in the maxillary sinus. Many patients in our series presented in advanced stages, in contrast to the rarity of aggressively presenting maxillary carcinomas among patients 
in western Europe. ${ }^{5}$ Since the maxillary sinus is an area surrounded by bone, significant bony involvement usually occurs prior to clinically apparent symptoms such as a cheek bulge which usually prompts medical consult. Patients may initially be diagnosed with some areas as unresectable, profoundly affecting prognosis.

The usual treatment for maxillary sinus SCC in our institution was surgery with radiotherapy. Radiotherapy with or without chemotherapy was usually advised for patients who were poor surgical candidates.

It has been established in the literature that histopathologic diagnosis is a strong factor for nodal metastasis with a primary SCC or undifferentiated carcinoma being the most likely to result in neck node metastasis. ${ }^{11}$ The grading of differentiation (well-differentiated, moderately-differentiated, and poorly-differentiated) has been found to have no significant difference in the likelihood for nodal metastasis." Only three (3) patients ( 2 well-differentiated SCC, 1 poorly differentiated SCC) out of the 22 patients in our study presented with positive cervical metastasis, relatively low compared to the high $(46 \%)$ incidence $(69$ out of 148 patients) noted in India., 3 This is consistent with findings in literature that nodal metastasis is uncommon in tumors without extensive lymphatic involvement, as is the case for the maxillary sinus. ${ }^{11}$ Studies such as by Le et al., found an overall incidence of 15.5\% for neck node metastases in patients with Maxillary SCC. ${ }^{12}$ Due to this low rate of neck node metastasis, elective neck dissection is not routinely done for patients with maxillary sinus SCC in our institution. Fine needle aspiration biopsy (FNAB) is likewise not done for clinically palpable neck nodes among patients with maxillary sinus SCC as these patients are treated with an additional neck dissection. Our results may underestimate the incidence of neck node metastases in our institution. However, FNAB may be explored as an option to determine neck node metastasis among patients who are not good candidates for surgical management.

There have been conflicting reports regarding factors influencing nodal metastasis, with some studies citing that extension of tumor outside of the maxillary sinus was closely related to the risk of cervical lymphadenopathy for maxillary sinus SCC.12,13 Another study reports that staging ( $\mathrm{T} 2$ in particular) confers a higher risk for nodal metastasis than T3 or T4 tumors. ${ }^{4}$ A study by Ahn et al. found that the increase in risk begins with $\mathrm{T} 2$ tumors and progresses to $\mathrm{T} 3$ and $\mathrm{T} 4$ tumors as well. ${ }^{15}$ All three patients who presented with positive cervical metastasis were staged as T4a tumors and 2 of the 3 patients were positive for tumor at the area of the pterygoid plates. These findings may be worth investigating in future research.

There are several limitations to this study. First, the limited sample size precludes the generalizability of our findings. Our series was also limited to the patients of one department (otorhinolaryngology) in our hospital and does not reflect the general surgery census of the same hospital. It is recommended that more patients with maxillary sinus SCC be included in future studies to gain more insight from trends observed in the data. The inclusion of imaging findings and post-treatment follow- up in the analysis will make the data more robust. Second, no association between the variables and the diagnosis of maxillary sinus SCC may be drawn from this series due to the limited number of patients included. The authors aimed to establish preliminary data for this condition and such associations may better be evaluated using other methods of statistical analysis in future studies with a larger sample size. A longer study period can also allow us to evaluate outcomes. Third, review of patient records limits the kind of data available. Clinicians usually do not ask about (or write down) technical risk factors such as exposure to substances and these may only be implied based on employment. In retrospect, broader inclusion criteria-including all types of maxillary sinus cancers - might have resulted in more patients and may have provided a more comprehensive understanding of the clinical behavior and outcomes of various maxillary sinus malignancies in our institution.

In conclusion, our series found that maxillary sinus SCC occurs more in males, with a maxillary mass as the most common chief complaint. Delays in treatment are usual, with a mean gap of 6 months between initial symptoms and consult. Neck node metastasis is uncommon and most patients undergo surgery with radiotherapy as treatment.

REFERENCES

1. Pilch B, Bouquot J, Thompson. Squamous cell carcinoma. In: Barnes L, Eveson J, Reichart P, and Sidransky D (editors). World Health Organization classification of tumours: Pathology and genetics of head and neck tumours. Geneva: IARC Press; 2005. p. 15-17.

2. Grant RN. Cancer statistics 1970. Ca Cancer J Clin 1970, 8: 6-20. As cited in Le QT, Fu KK, Kaplan MJ, Terris DJ, Fee WE, Goffinet DR. Lymph node metastasis in maxillary sinus carcinoma. Int J Radiat Oncol Biol Phys. 2000 Feb 1; 46(3): 541-549. PMID: 10701732

3. Santos MR, Servato JP, Cardoso SV, de Faria PR, Eisenberg AL, Dias FL, et al. Squamous cell carcinoma at maxillary sinus: clinicopathologic data in a single Brazilian institution with review of literature. Int J Clin Exp Pathol. 2014 Dec 1; 7(12): 8823-8832. PMID: 25674251 PMCID: PMC4313952.

4. Cantu G, Bimbi G, Miceli R, Mariani L, Colombo S, Riccio S, et al. Lymph node metastases in malignant tumors of the paranasal sinuses: prognostic value and treatment. Arch Otolaryngol Head Neck Surg. 2008 Feb; 134(2): 170-177. PMID 18283160.

5. Tiwari R, Hardillo JA, Mehta D, Slotman B, Tobi H, Croonenburg E, et al. Squamous cell carcinoma of maxillary sinus. Head Neck. 2000 Mar; 22(2): 164-169. PMID: 10679904.

6. Sakai S, Hohki A, Fuchihata H, Tanaka Y. Multidisciplinary treatment of maxillary sinus carcinoma. Cancer. 1983 Oct 15; 52(8): 1360-1364. PMID: 6193854.

7. Sharma S, Sharma SC, Singhal S, Mehra YN, Gupta BD, Ghoshal S, et al. Carcinoma of the maxillary antrum - A 10 year experience. Indian J Otolaryngol. 1991 Dec; 43 (4): 191-194.

8. Qureshi SS, Chaukar DA, Talole SD, D'Cruz AK. Squamous cell carcinoma of the maxillary sinus: a Tata Memorial Hospital experience. Indian J Cancer. 2006 Jan-Mar; 43(1): 26-29. PMID: 16763359.

9. Kondo A, Kurose M, Obata K, Yamamoto K, Murayama K, Shirasaki H. A clinical study of maxillary sinus squamous cell carcinoma. In: Himi K, Takano, K (editors). Excellence in Otolaryngology: 70 years of the Department of Otolaryngology of the Sapporo Medical University. Basel: Karger, 2016, p. 83-87.

10. St-Pierre S, Baker S. Squamous cell carcinoma of the maxillary sinus: analysis of 66 cases. Head Neck Surg. 1983 Jul-Aug; 5(6): 508-513. PMID: 6885504.

11. Jiang GL, Ang KK, Peters LJ, Wendt CD, Oswald MJ, Goepfert H. Maxillary sinus carcinomas: natural history and results of postoperative radiotherapy. Radiother Oncol. 1991 Jul; 21(3): 193200. PMID: 1924855

12. Le QT, Fu KK, Kaplan MJ, Terris DJ, Fee WE, Goffinet DR. Lymph node metastasis in maxillary sinus carcinoma. Int J Radiat Oncol Biol Phys. 2000 Feb 1: 46(3): 541-549. PMID 10701732.

13. Kim GE, Chung EJ, Lim JJ, Keum KC, Lee SW, Cho JH, et al. Clinical significance of neck node metastasis in squamous cell carcinoma of the maxillary antrum. Am J Otolaryngol. 1999 NovDec; 20(6): 383-390. PMID: 10609483.

14. Jeremic $B$, Nguyen-Tan PF, Bamberg B. Elective neck irradiation in locally advanced squamous cell carcinoma of the maxillary sinus: a review. J Cancer Res Clin Oncol. 2002 May; 128(5): 235238. PMID 12029438.

15. Ahn PH, Mitra N, Alonso-Basanta M, Palmer JN, Adappa ND, O'Malley BW Jr, et al. Risk of lymph node metastasis and recommendations for elective nodal treatment in squamous cel carcinoma of the nasal cavity and maxillary sinus: a SEER analysis. Acta Oncol. 2016 Sep - Oct; 55(9-10): 1107-1114. PMID 27685421. 